\title{
Entre estruturas e lembranças: análise da Fábrica de Cerâmica Castanheiro a partir da arqueologia industrial (São Raimundo Nonato/PI)
}

\author{
Alan Alves Ribeiro* \\ Alencar de Miranda Amaral** \\ Rosemary Aparecida Cardoso** *
}

\begin{abstract}
RIBEIRO, A.A.; AMARAL, A.M.; CARDOSO, R.A. Entre estruturas e lembranças: análise da Fábrica de Cerâmica Castanheiroa partir da arqueologia industrial (São Raimundo Nonato/PI). R. Museu Arq. Etn. 36: 212-231, 2021.
\end{abstract}

Resumo: Esta pesquisa tem como objeto de estudo a Fábrica de Cerâmica Castanheiro, que manteve suas atividades produtivas entre 1980 e 2003 no bairro Santa Luzia em São Raimundo Nonato/PI. Conjugando os preceitos teóricometodológicos da arqueologia industrial e urbana às narrativas de moradores locais, buscamos identificar os espaços produtivos da fábrica e problematizar sua importância para a organização espacial do bairro, avaliando como ela influenciou a urbanização, o processo de industrialização e o desenvolvimento econômico do município. Assim, por meio de prospecções, entrevistas semiestruturadas e levantamento documental, identificou-se que a fábrica era composta por cinco estruturas, com funcionalidades distintas: pátio de estocagem; galpão de produção (que abrigava os maquinários); local de armazenamento de matériaprima (caixão alimentador); galpão de secagem; e espaço associado ao processo de queima (fornos, chaminé, sistema subterrâneo de exaustão). Essas constatações permitiram elaborar um modelo 3D do local. Percebeu-se que a fábrica contribuiu para o crescimento urbano do bairro, fornecendo material para a construção de casas e para seu desenvolvimento socioeconômico, gerando empregos que atraiam pessoas para residirem no bairro e trabalharem na fábrica, e, consequentemente, uma expansão geográfica e demográfica. A fábrica empregou cem funcionários, o que demonstra que a economia municipal contava com uma produção industrial relevante e não se limitava aos setores de serviço e agropastoril.

Palavras-chave: Arqueologia industrial; Fábrica de Cerâmica Castanheiro; Modelo 3D.

\footnotetext{
* Graduado em Arqueologia pela Universidade Federal do Vale do São Francisco (Univasf). <allanalves763@gmail.com>

** Professor dos Colegiados de Graduação e PósGraduação de Arqueologia da Universidade Federal do Vale do São Francisco (Univasf). 〈alencar.univasf@gmail.com>

*** Colaboradora do Laboratório de Preservação

Patrimonial da Universidade Federal do Vale do

São Francisco (Univasf). <rsmrycardoso@gmail.com>
}

\section{Introdução}

Neste trabalho apresentamos uma pesquisa elaborada no município de São Raimundo Nonato/PI, especificadamente no bairro de Santa Luzia, que versa sobre a relação entre a Fábrica de Cerâmica Castanheiro e o 
desenvolvimento do bairro, quiçá da cidade, tendo em vista que a fábrica, ao gerar empregos, foi importante para o desenvolvimento socioeconômico do município.

Antes de narrarmos a história dessa fábrica, vale destacar que ela teve, no decorrer de seu período de funcionamento, três nomes diferentes: Cerâmica São Raimundo, PM Construtora e Fábrica de Cerâmica Castanheiro. No entanto, optamos por utilizar a denominação Fábrica de Cerâmica Castanheiro, pois a análise das estruturas arquitetônicas, assim como o modelo hipotético elaborado, refere-se ao momento de funcionamento da olaria.

Acreditamos que a fábrica de cerâmica é um patrimônio histórico e regional e pode ser considerada um dos espaços/monumentos mais emblemáticos de Santa Luzia, pois se trata de um local que influenciou, direta e indiretamente, o desenvolvimento econômico do bairro, visto que a fábrica empregou várias pessoas que foram morar em Santa Luzia por causa da oferta de empregos.

Esse tema foi proposto pois pode estimular e contribuir para um debate diretamente relacionado à identidade cultural que cerca o local, à memória, ao patrimônio e à valorização dos bens culturais. Salientamos a importância de conhecer nosso passado, para que assim se possa respeitar e preservar um patrimônio que tem grande significado para o bairro de Santa Luzia. Assim, ele foi considerado não apenas enquanto patrimônio local e regional, mas também como catalizador da identidade cultural agregada ao local.

Desse modo, esta pesquisa pretende, no geral, analisar a história da Fábrica de Cerâmica Castanheiro e compreender sua correlação com o desenvolvimento econômico da cidade de São Raimundo Nonato. Além disso, a partir do cruzamento das fontes orais, imagéticas e do contexto arqueológico, foi elaborado um modelo 3D da estrutura arquitetônica da fábrica.

\section{Aportes conceituais}

O desenvolvimento da arqueologia urbana enquanto subdisciplina da arqueologia ocorreu inicialmente na Europa, especialmente em países como Inglaterra, França, Itália e Portugal, entre outros (Noivo 2010). No contexto português, merecem menção os debates em torno da diferenciação entre "intervenções arqueológicas urbanas" e "arqueologia urbana”, ou entre "arqueologia das cidades vivas" ou "mortas", como um dos marcos para definir esse campo de pesquisa.

Nesse cenário, a arqueologia urbana se estabelece como um ramo de pesquisa específico, com características próprias, como sugere Alarcão:

Parece-me pacifico dizer que a Arqueologia Urbana e Arqueologia de cidades antigas, romanas ou medievais não são sinônimas. Se os termos fossem equivalentes, teríamos que considerar como Arqueologia Urbana as escavações de Conimbriga, Miróbriga ou Troia, sitios hoje desertos ou, para recuperar uma expressão do século XIX, cidades mortas (Alarcão 1994: 59-60).

\section{As intervenções arqueológicas} empreendidas em cidades e centros urbanos foram fundamentais na formação do conceito de arqueologia urbana, que se difere por atuar em contextos relacionados ao meio urbano e, desse modo, amplia os campos de estudo da arqueologia, fomentando o desenvolvimento de novos eixos temáticos, teóricos e interdisciplinares, dentre os quais merecem destaque a arqueologia do urbanismo, a arqueologia em meio urbano e a Arqueologia das Cidades Vivas (Silva 1999).

Segundo Silva (1999), a arqueologia do urbanismo privilegia a abordagem de práticas e métodos desenvolvidos pela arqueologia para estudar os acontecimentos ocorridos no meio urbano. Essas pesquisas podem ser realizadas tanto em cidades atuais quanto em cidades "mortas", onde já não existe mais nenhum tipo de ocupação recente. Por sua vez, a arqueologia em meio urbano está associada ao lugar no qual a atividade arqueológica se realiza, ou seja, o meio urbano. Assim, o contexto arqueológico visado pela intervenção não precisa estar relacionado diretamente aos eventos e/ou 
cultura material associados à realidade urbana atual (Silva 1999). Por fim, na arqueologia das cidades vivas os trabalhos arqueológicos são direcionados à análise de contextos em cidades ainda em "funcionamento", ou seja, são abordados espaços, estruturas e materiais que integram a paisagem e o contexto de cidades povoadas atualmente (Silva 1999).

De certo modo, a perspectiva da arqueologia das cidades vivas é a que mais se aproxima deste estudo de caso, visto que analisaremos um local que está inserido e relacionado ao contexto urbano de São Raimundo Nonato. Assim, essa abordagem tem o potencial de ajudar a compreender a história, a criação e o desenvolvimento da fábrica, além de sua relação com o bairro de Santa Luzia.

Outro referencial importante para esta pesquisa são os conceitos e discussões vinculados à arqueologia industrial. Em meados da década de 1960, a arqueologia industrial se consolidou na Inglaterra devido à necessidade de proteger alguns monumentos erguidos durante a Revolução Industrial. Houve, entre acadêmicos e amadores ingleses, a preocupação com a conservação de locais e edificações que representassem os marcos do desenvolvimento industrial do país. Do mesmo modo, nas décadas subsequentes, essa linha de raciocínio foi seguida por pessoas de diferentes países que estavam preocupadas com a preservação de antigos vestígios da industrialização em suas nações, inaugurando, assim, um campo de investigação para a arqueologia (Clarke, Palmer \& Neaverson 1999).

Inicialmente, essa linha de pesquisa foi negligenciada pela comunidade acadêmica, visto que os pesquisadores da época não reconheciam o caráter arqueológico desses contextos. Eles consideravam que esses objetos de estudo eram "recentes", e que as metodologias empregadas, na maioria das vezes, destinavam-se à conservação e descrição das estruturas e contextos fabris, muito distintas dos "métodos tradicionais" da arqueologia, como as escavações e prospecções (Foley 1968).

Nos últimos anos os pesquisadores dedicados à arqueologia industrial têm ampliado o escopo de suas investigações, dedicando-se tanto à reconstrução dos espaços fabris e dos meios de produção quanto às relações sociais e simbólicas inerentes às sociedades industriais, que são materializadas em diferentes aspectos do contexto fabril. Portanto, a arqueologia industrial gradativamente busca não se limitar à formulação de uma "história da ciência ou das técnicas”. Ao contrário, dedica-se a problematizar como o fenômeno da industrialização afetou diferentes aspectos (econômicos, sociais, técnicos, simbólicos etc.) das sociedades em um passado recente, mantendo sua relevância até a contemporaneidade.

Por conseguinte, a arqueologia industrial visa documentar, investigar e analisar vestígios de sociedades que participaram do processo fabril utilizando métodos arqueológicos como escavação, prospecção, análise documental, classificação, registros fotográficos, orais, textuais e filmográficos, além da análise arquitetônica e de elementos da paisagem que ajudam a entender as relações sociais, especialmente aquelas atinentes às questões de trabalho e produção.

No cenário nacional, de certo modo, podese afirmar que ações relativas ao patrimônio industrial aconteceram antes mesmo da difusão do termo arqueologia industrial. Exemplos disso são o tombamento da fábrica de Ferro Patriótica, localizada em Ouro Preto/MG, realizado pelo Serviço de Patrimônio Histórico e Artístico Nacional (Sphan) em 1938; e o registro da Real Fábrica de Ferro São João de Ipanema, em Iperó/SP, feito pelo Instituto do Patrimônio Histórico e Artístico Nacional (Iphan) em 1964 (Santos 2014).

No âmbito acadêmico, o tema começa a ganhar espaço a partir 1974, com o trabalho seminal do historiador Warren Dean "A fábrica São Luiz de Itu: um estudo de Arqueologia Industrial”. Além disso, entre os idos de 1986 e 1999 os Seminários de História e Energia promovidos pela Eletropaulo tornaram-se um veículo importante para promover e divulgar pesquisas associadas à arqueologia industrial (Santos 2014: 48).

A partir dos anos 2000 ocorre um crescimento significativo no número de trabalhos em arqueologia industrial nos 
programas de pós-graduação no Brasil. Dentre essas pesquisas merece menção a dissertação de Vichnewski (2004), intitulada As indústrias Matarazzo no Interior Paulista: arquitetura fabril e patrimônio industrial (1920-1960).

Nessa pesquisa o autor faz um estudo com 24 indústrias de beneficiamento de algodão instaladas em dezessete cidades no interior paulista entre os anos de $1920 \mathrm{e}$ 1960. O principal objetivo foi catalogar as indústrias Matarazzo e o registrar o patrimônio industrial do interior de São Paulo. Para tanto, Vichnewski faz o levantamento de fotos antigas, informações de arquivos, jornais de época, mapas e plantas fabris, além de realizar visitas técnicas sistemáticas e elaborar uma classificação das indústrias segundo os padrões tecnológicos, morfológicos e arquitetônicos. Tudo isso, segundo o autor, tendo como "finalidade compreender, explicar e registrar, pelo menos, parte da industrialização ocorrida no interior do estado de São Paulo" (Vichnewski 2004: 15).

Outro trabalho que gostaríamos de destacar é o artigo "Arqueologia em fábricas paulistas, entre chaminés e estacionamentos: ou dos métodos para escavar uma fábrica”, escrito por Souza (2013). Nessa obra Souza busca apresentar exemplos de como a arqueologia dialoga com os contextos fabris e desenvolve métodos específicos para lidar com tais vestígios. $\mathrm{O}$ autor tece considerações em torno da arqueologia da industrialização no estado de São Paulo e de questões referentes à inserção da arqueologia no âmbito das políticas de preservação do patrimônio industrial.

$\mathrm{O}$ artigo se aproxima de nossa pesquisa ao abordar a forma como as chaminés e prédios das fábricas se tornam verdadeiros marcos paisagísticos da industrialização paulistana, devendo, portanto, serem foco de atenção e proteção do poder público (Souza 2013).

Também defendemos que a chaminé da Cerâmica Castanheiro é um monumento relevante para a história e as memórias dos moradores locais, além de ser local de destaque na paisagem urbana do bairro Santa Luzia, em meio às casas que foram construídas ao redor da fábrica. O cenário da chaminé isolada em meio às ruínas da Fábrica de Cerâmica Castanheiro tem se tornado um grande marco para bairro, pois chama a atenção de todos que passam pelo local, instigando a curiosidade e promovendo lembranças.

No Piauí também foram desenvolvidos alguns trabalhos relacionados à arqueologia industrial. Dentre eles podemos citar a pesquisa realizada na Usina Bonita ${ }^{2}$, no município de Floriano, que subsidiou seu tombamento em nível estadual, além do estudo sobre o conjunto histórico Estação Ferroviária, em Teresina ${ }^{3}$.

Apesar de limitado, esse breve recorte demonstra como os trabalhos em arqueologia industrial podem dedicar-se tanto às reflexões sobre os problemas associados ao contexto da expansão do capitalismo quanto às análises das indústrias como unidades produtivas. Nesse mister, considerando os objetivos e a especificidade do objeto de estudo desta pesquisa, a arqueologia industrial tem o potencial de auxiliar a compreender a organização espacial e a lógica produtiva da Fábrica de Cerâmica Castanheiro.

2 "A Usina Maria Bonita, inicialmente, foi uma pequena Capela da então Colônia de São Pedro de Alcântara. Localizada nos terrenos do Estabelecimento Rural, próxima a outro edifício onde funcionava a escola de artes e oficios para filhos dos negros alforriados, a citada Capela compunha o conjunto arquitetônico conhecido como Área. Com a desativação da Capela e com a expansão do núcleo comunitário, já com foros de cidade, a área do Estabelecimento Rural não merecia tanto interesse por parte dos seus habitantes. A 06 de fevereiro de 1922 o Intendente Antônio Luiz de Área Leão celebrou com a Casa do Maranhão um convênio para a instalação de uma máquina geradora de luz elétrica para a cidade. Em 24 de fevereiro do ano de 1924, foi feita a inauguração da citada Usina Maria Bonita. Esse nome deve-se à existência de um motor anterior, de pouca potência, chamado 'Lampião"' (Secult 2018: 16).

3 A Estação Ferroviária foi inaugurada em 1926 e tombada em 2003. Segundo Claudiana Crus dos Anjos, superintendente do Iphan no Piauí, a ferrovia em Teresina significou o acesso ao mar e a inserção de sua produção agrícola e industrial na economia do país, sendo esse um dos motivos que evidencia a importância do Conjunto da Estação Ferroviária de Teresina para o desenvolvimento social e cultural do Piauí. O conjunto ajuda a compreender como foi estruturada a urbanização da cidade e do território nacional. A superintendente destacou, ainda, que o tombamento foi muito significativo para o desenvolvimento econômico e social do estado, viabilizando projetos voltados para a área da cultura e do turismo. "Ter um bem reconhecido acaba facilitando a obtenção de recursos para esses projetos” (Agência Brasil 2013). 
Como discutido por Cerdá (2008), o emprego do método arqueológico para o estudo de todos os tipos de restos materiais deixados pela sociedade industrial capitalista potencializa a geração de informações e dados que auxiliam a compreender e problematizar diferentes meandros das sociedades industriais.

Em acordo com essa perspectiva, acreditamos que esta pesquisa possa contribuir com reflexões iniciais sobre a influência que a Fábrica de Cerâmica Castanheiro exerceu no desenvolvimento econômico do bairro Santa Luzia. E, posteriormente, por meio de novos estudos, será possível formular análises mais detalhadas sobre a importância do setor industrial na cidade de São Raimundo Nonato.

Assim, em nossa região, a relevância de estudos em arqueologia industrial é assegurada pelo seu potencial de contribuir para a compreensão e divulgação de um aspecto importante da história local, apesar de pouco estudado. Ou seja, esses estudos são importantes por discutirem a lógica de funcionamento e o impacto da instalação de empreendimentos industriais (aqui representados pela Fábrica de Cerâmica Castanheiro) em pequenos municípios rurais do Nordeste, como é o caso da cidade de São Raimundo Nonato.

\section{Métodos}

Em uma investigação arqueológica, utilizar todas as fontes disponíveis é sempre recomendável ${ }^{4}$. Assim sendo, para além da materialidade presente no contexto do sítio, buscamos respaldo em dados documentais, iconográficos/imagéticos e orais.

4 "Cualquier escrito, resto o vestigio del pasado, lejano o próximo, es útil si aporta alguna información. No hay un tipo de datos seleccionables a priori, por lo que cualquier documento es una fuente potencial de información. Todo depende de las cuestiones o los problemas definidos por la investigación....

No ha un tipo de fuentes más importante que otro, ninguna tiene preeminencia sobre las demás. Las fuentes escritas no son subsidiarias de las demás" (Cerdà 2008: 132).
Dessa forma, inicialmente realizou-se um levantamento bibliográfico ${ }^{5}$ direcionado para a história local e estudos de casos em arqueologia urbana e arqueologia industrial sobre contextos fabris, o que contribuiu para a contextualização e formulação de insights sobre nosso objeto de estudo. Em seguida, definimos as estratégias para coletar informações orais e formar uma rede de colaboradores. Para coletar os dados, optouse por realizar entrevistas semiestruturadas ${ }^{6}$, técnica que atende principalmente às finalidades exploratórias e possibilita obter o maior número possível de informações de forma detalhada sobre determinado tema, segundo a visão do entrevistado (Cardoso 2013).

Tal como Moraes (2005: 92), acreditamos que, ao trabalhar com narrativas orais e abordar os processos sociais de construção e transmissão da memória, estamos lidando com "um complexo e tenso campo de disputa de sentidos em que a mobilização e circulação dos discursos" não são alheias aos interesses dos narradores? ${ }^{7}$ Isso posto,

5 Em linhas gerais, a pesquisa bibliográfica é um apanhado sobre os principais trabalhos científicos já realizados sobre o tema escolhido e que são revestidos de importância por serem capazes de fornecer dados atuais e relevantes. Ela abrange publicações avulsas, livros, jornais, revistas, vídeos, site etc. Esse levantamento é importante tanto para os estudos baseados em dados originais, colhidos numa pesquisa de campo, quanto para aqueles inteiramente baseados em documentos (Luna 1999).

6 As entrevistas semiestruturadas combinam perguntas abertas e fechadas, nas quais o informante tem a possibilidade de discorrer sobre o tema proposto. $\mathrm{O}$ pesquisador deve seguir um conjunto de questões previamente definidas, mas em um contexto muito semelhante ao de uma conversa informal. O entrevistador deve ficar atento para dirigir, quando achar oportuno, a discussão para o assunto que o interessa, fazendo perguntas adicionais para elucidar questões que não ficaram claras ou para ajudar a recompor o contexto da entrevista caso o informante tenha fugido ao tema ou tenha dificuldades com ele. Esse tipo de entrevista é muito utilizado quando se deseja delimitar o volume das informações, obtendo assim um direcionamento maior para o tema, intervindo a fim de que os objetivos sejam alcançados (Boni \& Quaresma 2005).

7 "a memória é um esforço organizado de intervenção na própria conjuntura, implicando intencionalidade sobre o modo de constituição simbólica, relacional e discursiva de realidades por meio do Estado, de movimentos sociais, de saberes, institucionais ou não, e de interesses socioeconômicos. A memória social deve ser pensada em seu contexto e produção sócio-históricos. Considerada à luz de seu sentido plural, é a expressão partilhada de um sentimento e de um modo de compreender e de se relacionar 
vale frisar que, ao lançarmos mão das fontes orais, nosso objetivo não se volta simplesmente ao escrutínio da "veracidade" das informações compartilhadas por nossos colaboradores, mas sim para o reconhecimento da existência e validade das múltiplas interpretações sobre o passado e sobre o patrimônio arqueológico. Portanto, acreditamos que nossa compreensão a respeito do passado e dos bens de valor histórico, arqueológico e cultural, pode ser expandida quando nos predispomos a valorizar o que a comunidade local tem a dizer sobre eles. Como discutido por Hodder (1999), é preciso que a Arqueologia e as ciências de modo geral progressivamente abracem a diversidade metodológica e teórica, permitindo que a "interpretação" do passado esteja aberta para outras vozes, sem com isso abandonar a necessária coerência e plausibilidade entre dados, contextos e interpretações.

Assim sendo, nesta pesquisa contamos com a colaboração de três moradoras do bairro Santa Luzia (sra. Nidia Helena Alves de Araújo, sra. Estelita Miranda Damasceno e sra. Maria Ducenildes de Negreiros Damasceno), do proprietário da fábrica (sr. Péricles Macário de Castro) e de um antigo funcionário da fábrica (sr. Raimundo Nunes Ribeiro Junior).

Por sua vez, para o levantamento documental e iconográfico, realizamos consultas no Cartório Regional de São Raimundo Nonato, além de contarmos com a colaboração do antigo proprietário da Cerâmica Castanheiro e do editor do website www.saoraimundo.com.

A análise da fonte documental é indispensável à arqueologia industrial, já que tem a finalidade de auxiliar na contextualização histórica. No entanto, os documentos escritos estão carregados da intencionalidade de quem os escreveu (Santos 2014). Por outro lado, sua utilização possibilita formular hipóteses que podem ser confirmadas, modificadas ou postas de lado à medida que a investigação avança (Cerdà 2008).

A análise das fontes iconográficas ajuda a reconhecer alguns espaços industriais

no mundo, uma singularidade social, bem como um campo de lutas simbólicas, discursivas e relacionais, lembranças, silêncios e esquecimentos" (Moraes 2005: 97). desaparecidos ou que foram modificados ao longo do tempo. $\mathrm{O}$ intuito desta análise foi compreender os espaços do cotidiano fabril e detectar a transformação da paisagem ao longo do tempo.

Nessa perspectiva, Zarankin \& Senatore (1996) comentam que nas pesquisas históricas:

\section{La información histórica cumple un} papel muy especifico dentro de este tipo de investigaciones. En primer lugar, es revisada como parte de los antecedentes del tema a ser abordado. Esto permite conocer y definir el contexto histórico general en el cual se inserta el problema arqueológico. Sin embargo, es fundamental dentro de este enfoque que la evidencia arqueológica se presenta como base empirica sobre la que se testean las hipótesis de trabajo. Por lo tanto, las escalas analíticas deben contemplar que los enunciados puedan ser abordados arqueológicamente (Zarankin \& Senatore 1996: 4).

Sendo assim, a análise das fontes textuais e iconográficas proporcionou o conhecimento prévio do objeto de estudo, além de permitir a formulação de algumas hipóteses sobre determinados elementos materiais que estavam inseridos dentro do contexto produtivo e social da Fábrica de Cerâmica Castanheiro.

Por fim, mas não menos importante, prospectou-se o sítio arqueológico com vistas a identificar, registrar e analisar as estruturas e materialidades associadas ao contexto fabril, de forma que fosse possivel compreender a organização de seus espaços de trabalho. Assim, além do registro fotográfico, medimos as estruturas, o que possibilitou elaborar uma planta baixa e o modelo 3D da fábrica por meio dos softwares Sketchup e Lumion8, fornecendo-nos uma representação de como seria o prédio na época de funcionamento da Cerâmica Castanheiro.

\section{A história do bairro Santa Luzia através da lembrança de seus moradores}

Quanto a sua localização, o bairro Santa Luzia está inserido na cidade de São Raimundo 
Nonato $^{8}$, no interior do estado do Piauí, a $550 \mathrm{~km}$ de sua capital.

O bairro Santa Luzia anteriormente se chamava Barro. Acredita-se que essa toponímia é uma derivação do nome da grande fazenda que existia na área, conhecida como Barro Vermelho. Ainda hoje muitos moradores da região continuam chamando o bairro Santa Luzia de Barro. Em nosso levantamento, conseguimos identificar um documento, cedido pelo Cartório Regional de São Raimundo Nonato, que comprova a compra e venda de terras em 1965, quando o bairro ainda era denominado Barro. O fato de o bairro possuir, atualmente, o nome de uma santa, indica como o contexto religioso é intrínseco a seu desenvolvimento, uma vez que isso ocorreu a partir da criação da igreja homônima, em meados de 1930. Mas, do ponto de vista da burocracia oficial, a mudança no nome da localidade ocorreu somente em 1970, no mandato do prefeito Pedro Macário.

As primeiras instalações no bairro se deram a partir de fazendas, assim como na própria cidade de São Raimundo Nonato e nas regiões circunvizinhas. Atualmente, no bairro Santa Luzia, ainda existem algumas fazendas que estão em atividade desde o início do processo de urbanização da área, sendo possível identificar também as "primeiras casas" da localidade.

Segundo a sra. Estelita, uma das poucas construções desse período que ainda permanecem "em pé" seria a antiga "casa do Sr. Quinco", que teria sido construída por ele em meados de 1916. A casa (Fig. 1) foi construída em taipa, também conhecida como pau-a-pique. Trata-se de uma técnica vernácula em que as paredes são armadas com madeira, preenchidas com barro e fibra e cobertas com telhas de olaria.

Por sua vez, a Sra. Maria Dulcenildes conta que uma das construções mais antigas do bairro, que seria "do tempo das fazendas", é a casa pertencente ao sr. Evandro Macêdo,

8 São Raimundo Nonato é conhecida como a capital da pré-história devido às pesquisas arqueológicas que ocorrem há mais de quarenta anos nessa região que abriga dois parques nacionais, a Serra da Capivara e a Serra das Confusões (Ribeiro \& Alves 2017). Todavia, apesar disso, as pesquisas arqueológicas sobre o contexto urbano e industrial da região são praticamente inexistentes. construída em 1930 pelo padre Ângelo, um dos primeiros padres a celebrar uma missa no bairro de Santa Luzia. Segundo ela, na década de 1960 seu pai comprou uma propriedade que hoje pertence ao hotel Serra da Capivara e que fazia divisa com a propriedade do sr. Evandro Macêdo. A propriedade do pai da sra. Maria Dulcenildes era ligada à propriedade da família do deputado Marcelo Castro, ao lado da qual estavam as terras da sra. Celça Alves de França, e um pouco mais acima a roça do sr. Quinco, que hoje pertence à família Damasceno.

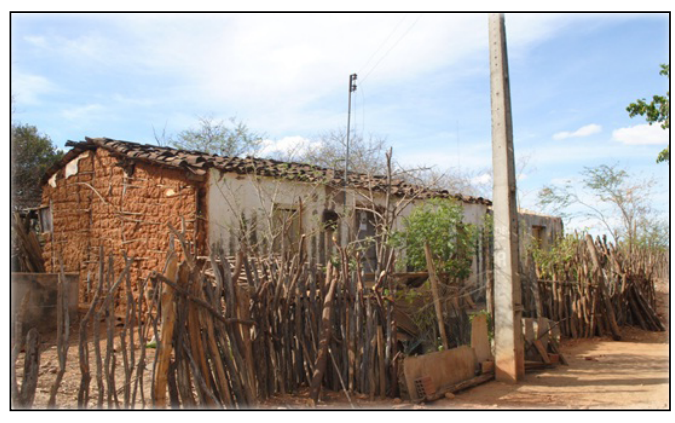

Fig. 1. Casa de taipa do sr. Quinco, atualmente pertencente à família Damasceno.

Fonte: Ribeiro (2018: 34).

Essas informações indicam que essas propriedades e a casa do sr. Quinco são anteriores ao período da construção da igreja do bairro de Santa Luiza, um cenário corolário ao processo de ocupação do interior nordestino.

De modo geral, no Nordeste, primeiro surgiram as fazendas destinadas à criação de caprinos ou bovinos. Para exercer essas atividades algumas famílias eram levadas para trabalhar e morar nesses locais, surgindo, assim, os primeiros povoados. Em seguida, a Igreja Católica Apostólica Romana enviava religiosos para difundir sertão adentro a fé católica e logo eram construídas as igrejas. Assim, com o passar dos anos, igrejas foram construídas em vários locais, como foi o caso da Igreja de Santa Luzia, cuja história é conhecida de maneira mais viável por meio dos relatos orais e lembranças dos moradores locais, como narra a sra. Nídia, 
Teve as missões não sei o ano ao certo [...]. Teve as missões o pessoal diz que a igreja tem entorno de 90 anos, era só uma capelinha pequeninha só de taipa, depois que veio fazer de alvenaria. Está com 17 anos que foi reformada na minha coordenação que foi implantada a sacristia o Santíssimo, todo concerto foi feito na nossa gestão, a forma de arrecadação da igreja, só tem $10 \%$ destinado à nossa igreja, o restante vai para a igreja nossa senhora das mercês, esse ano vai ser destinado $50 \%$ do dinheiro dos festejos para nossa igreja (Ribeiro 2018: 35).

Segundo a sra. Nídia, a primeira novena realizada na Igreja de Santa Luzia ocorreu na década de 1930. A missa foi rezada pelo padre Ângelo, responsável pela igreja naquela época. A partir de então o novenário foi realizado todos os anos em devoção a Santa Luzia. Nessas ocasiões realiza-se uma arrecadação entre os fiéis para melhorar a igreja e financiar seus projetos sociais.

O primeiro padre a celebrar missa no bairro chamava padre Ângelo, Tia Ana era zeladora, depois passou para Francisca de Assis, nós ajudávamos ela! Ela faleceu, têm uns dois anos (Ribeiro 2018: 35).

Assim, se no início a área do bairro de Santa Luzia era inteiramente tomada por fazendas de distintos proprietários, com o crescimento da ocupação da área, que coincide com o período de construção da igreja, algumas propriedades foram vendidas e os novos proprietários foram loteando suas terras. Desse modo, foram se instalando no bairro pessoas que não faziam parte das famílias "tradicionais" que viviam na localidade, e, com isso, gradativamente o bairro foi adquirindo uma configuração urbana e abandonando a lógica espacial rural.

Questões políticas também influenciaram determinadas modificações no bairro. Em sua gestão, o vice-prefeito Pedro Macário fez algumas desapropriações de terra no bairro de Santa Luzia, "invadindo" as terras do sr. Anfilofilo Alves de França, que era o avô de nossa entrevistada, a sra. Nídia. $\mathrm{Na}$ área desapropriada foi construído o conjunto habitacional conhecido como Cohab Santa Luzia. Além disso, entre as propriedades desapropriadas por Pedro Macário estão as terras onde se localiza a Fábrica de Cerâmica Castanheiro.

Apesar das polêmicas que envolvem esses atos de desapropriação, segundo os relatos de alguns entrevistados, durante seu governo, Pedro Macário fez muitas benfeitorias, não só para o bairro de Santa Luzia, mas também para toda a cidade de São Raimundo Nonato.

\section{História da Fábrica de Cerâmica Castanheiro}

Segundo a versão registrada durante as entrevistas com o sr. Péricles Macário de Castro, a Fábrica de Cerâmica Castanheiro foi implantada no bairro de Santa Luzia com o objetivo de produzir material construtivo (telhas e tijolos) para um projeto de construção de casas populares realizado pelo governo federal em todo o Brasil, que também seria executado em São Raimundo Nonato. O relato coletado informa que o presidente Figueiredo, em uma reunião realizada com seus ministros, anunciou a construção de conjuntos habitacionais em todo o território brasileiro. Nessa reunião o ministro da agricultura Delfin Neto questionou se o parque de cerâmica industrial do Brasil atenderia a demanda de fabricação de tijolos e telhas para a construção dos conjuntos habitacionais (Ribeiro 2018). Nas palavras do sr. Péricles,

\section{O ministro Delfin Neto que era da} agricultura, já tinha sido ministro do planejamento da fazenda, perguntou na reunião se o parque industrial do Brasil atenderia tanto o material que ia ser usado num periodo curto de tempo que era pra ser de 80 a 85 que era o final do governo militar, ai foram ver que precisaria financiar a cerâmica e ai o governo federal através do BNH, começou a financiar através do programa de casas de Cohab, as cerâmicas em todo o nordeste, principalmente aqui nas principais cidades, aqui no Piauí no caso, São Raimundo, Oeiras, Floriano e etc. (Ribeiro 2018: 38).

De acordo com Lucchese \& Rossetto (2018), para colocar em prática tal projeto o presidente 
Castelo Branco assinou a Lei 4.380, de 21 de agosto de 1964 (Brasil 1964), criando o Serviço Federal de Habitação e Urbanismo (Serfhau), o Banco Nacional de Habitação (BNH) e o Sistema Financeiro de Habitação (SFH), possibilitando, assim, meios para suprir a carência de moradias naquela época ${ }^{9}$. Esses órgãos utilizavam os recursos financeiros da caderneta de poupança e do FGTS (Fundo de Garantia por Tempo de Serviço) regidos pelo BNH.

Nesse contexto, um empresário da cidade de São Raimundo Nonato, que na época trabalhava na fabricação de balas e doces, conhecido popularmente como Raimundinho da Ótica, viu na abertura de uma fábrica de tijolos e telhas na região uma grande oportunidade de negócio. Assim teria surgido a ideia de implementação da "Cerâmica São Raimundo", cuja produção iria atender a demanda de todo o sul do Piauí e as cidades mais próximas de outros estados que fazem divisa com o Piauí, tais como Petrolina/PE, Remanso/BA, Pilão Arcado/BA, Campo Alegre de Lourdes/BA e Casa Nova/BA (Ribeiro 2018).

Por meio do BNH o sr. Raimundinho da Ótica conseguiu o financiamento para colocar seu projeto em andamento, aproveitando a oportunidade gerada pela implantação de outras fábricas nas principais cidades do sul do Piauí, tais como Oeiras, Floriano e Picos. Ele inaugurou a fábrica em 1980, comprando todo o maquinário da empresa Verde, localizada na cidade de Itu/SP, que era especializada na fabricação de maquinários para olaria.

À época de sua implantação a fábrica tinha capacidade para produzir 10 mil tijolos por dia. Contudo, essa quantidade não atendia a demanda de todas as cidades vizinhas. Posteriormente, o sr. Raimundinho acabou vendendo a fábrica por não obter sucesso no seu negócio.

A fábrica foi comprada por um engenheiro civil, o sr. Péricles Macário, em 1984. Como informado por nosso colaborador, a fábrica

9 "Art. 1O Govêrno Federal, através do Ministro de Planejamento, formulará a política nacional de habitação e de planejamento territorial, coordenando a ação dos órgãos públicos e orientando a iniciativa privada no sentido de estimular a construção de habitações de interesse social e o financiamento da aquisição da casa própria, especialmente pelas classes da população de menor renda" (Brasil 1964). foi adquira em conjunto com o Banco do Estado. O "fracasso" inicial da fábrica foi ocasionado por um erro do projeto técnico, pois o maquinário tinha capacidade para produzir 80 mil tijolos por dia. No entanto, esse erro permitia que ela produzisse somente $10 \mathrm{mil}$ tijolos por dia. Nas palavras do próprio sr. Péricles Macário:

Nós já viemos adquirir ela em 1984, deu um problema eu acredito que foi na parte de configuração, ou seja, ele comprou uma máquina muito grande só que os fornos a quantidade era menos, até comparava na época que era como se você comprasse um cavalo mecânico que tem condição de puxar uma carreta de 60 toneladas, ai só queimava 10.000 tijolos por dia, ou seja, era uma carreta puxando uma carroceria de um Chevrolet e ai um caminhão toco, ai tava desconfigurado e ai foi o problema que ele não teve muito sucesso pra frente ai nos adquirimos ela junto ao banco do estado ia leiloar e nós entramos e fizemos uma composição com o banco do estado e com o Raimundinho da ótica e adquirimos ela de 1984 pra 1985 (Ribeiro 2018: 39).

Logo após efetuar a compra da fábrica, o sr. Péricles observou esse erro na configuração da fábrica e tentou solucionar o problema construindo mais quatro fornos-chaminés. Desse modo, a fábrica ficou com um total de dez fornos, permitindo que alcançasse toda sua capacidade produtiva e atendesse à demanda solicitada.

Para iniciar a fabricação do material construtivo o sr. Raimundinho levou um funcionário de fora, chamado de Mestre Raimundo, para treinar vinte funcionários que iriam trabalhar na fábrica. A maioria dos funcionários residia no bairro de Santa Luzia e morava próximo à fábrica. Logo após o treinamento Mestre Raimundo acabou se estabelecendo na cidade, residindo em São Raimundo Nonato até seus últimos dias de vida.

A matéria-prima para fabricação dos materiais produzidos pela fábrica era extraída na fazenda Lagoa, que hoje em dia se chama Novo Zabelê. O sr. Raimundinho comprou uma propriedade na Fazenda Lagoa com o objetivo 
de extrair matéria-prima necessária para produzir telhas e tijolos. Contudo, devido à distância, após algum tempo a extração de matéria-prima passou a ser realizada em Vereda, que fica a cerca de $3 \mathrm{~km}$ da fábrica, tornado mais viável seu funcionamento. Esses fatos foram narrados pelo sr. Raimundo Nunes Ribeiro Juniors, sobrinho do sr. Raimundinho da Ótica e ex-funcionário da fábrica. Segundo ele:

Me lembro bem que, quem veio instalar essas máquinas lá na fábrica foi o já falecido, a gente chamava ele de mestre Raimundo, meu tio buscou ele em uma cidade chamada de Jaicós, ai passou a ser morador de São Raimundo aí ele passou a residir aqui até a morte. O barro para produzir as telhas e os tijolos, o material né, a gente buscava na Vereda, ali próximo, lá localidade Vereda. Mas, de início meu tio comprou uma fazenda chamada Fazenda Lagoa que hoje é assentamento o Novo Zabelê né, lá era a Fazenda Lagoa era dos padres era da Ordem Mercedária, então meu tio comprou essa fazenda lá e aí ele viu que lá tinha um barro que era produtivo, então ele comprou em função essa fábrica, ai entorno dessa fazenda também, já o barro sendo dele também aí com o tempo pegava a segunda parte de trabalho mudaram para vereda que era mais próximo (Ribeiro 2018: 40).

A partir do momento que a fábrica passou a pertencer ao sr. Péricles Macário o número de funcionários aumentou. Em média sessenta funcionários trabalhavam diretamente dentro da fábrica, totalizando aproximadamente cem funcionários que trabalhavam direta e indiretamente na fábrica. A fábrica teve um impacto bastante significativo no crescimento geográfico e espacial do bairro Santa Luzia, pois, além de atrair os trabalhadores que passaram a residir em seu entorno ou em áreas próximas, a partir de sua instalação teve início a construção do conjunto habitacional, a "Cohab", acarretando um crescimento bastante significativo para o bairro.

A fábrica funcionou, sob a posse do sr. Péricles Macário, entre 1984 e 2003. Entre 1984 e 1990 a fábrica se chamava PM Construtora, pois o banco precisava de uma empresa que tivesse capital para comprovar renda no seu financiamento. Anos depois, após a vinda da fiscalização em 1990, foi necessário que a fábrica mudasse o nome da razão social, porque a empresa PM Construtora trabalhava com construção e não com produção fabril. Assim, a partir de 1990 a fábrica passou a se chamar Cerâmica Castanheiro e ficou com esse nome até seu fechamento. Nas palavras do sr. Péricles,

\footnotetext{
É porque era "Cerâmica São Raimundo" ai nos botamos inicialmente botamos o nome da nossa empresa que era PM Construtora, por que lá pro banco precisava de uma empresa que já tivesse um certo capital ai nós compramos com o nome de PM Construtora ai no ano 86 foi quando veio uma fiscalização e disse não tem que botar outra porque essa ai é construtora não é cerâmica ai nós foi mudar a razão social tinha outra empresa a Cerâmica Castanheiro a partir de 90 até 2003 quando ela fechou ficou esses 13 anos como Cerâmica Castanheiro (Ribeiro 2018: 41).
}

Segundo nossos entrevistados, o fechamento da Fábrica de Cerâmica Castanheiro ocorreu devido ao mau planejamento em relação ao projeto técnico inicial da fábrica e a escolha do local de instalação. Um dos principais motivos que ocasionou seu fechamento foi a logística para ter acesso à matéria-prima que era usada na confecção dos produtos, ou seja, a argila e o combustível para queima. Segundo informações do sr. Péricles Macário:

A nossa parada principal foi porque a nossa matéria-prima, outra coisa, o Raimundinho, instalou erradamente a cerâmica, por que você instala Cerâmica geralmente é no local onde há jazida e material ele instalou aqui em São Raimundo tinha pouco material, pra telha mesmo tinha que buscar em Coronel José Dias que era 'Várzea Grande' (Era o antigo nome que a cidade de Coronel Jose Dias) antigamente e o barro a gente buscava aqui na Vereda (Uma localidade próximo de São Raimundo Nonato), fica perto uns $5 \mathrm{~km}$, mas, mesmo lá foi ficando difícil o material então estava ficando muito inviável tanto o material como a argila que era pra fazer o bloco como também o material 
de queima que era a lenha por que aqui fica próximo ao parque, tinha que pegar lenha pra outro lado em sentido aqui pra Bahia, a gente tirava lenha pro lado de cá, por que por aqui o Ibama não permitia (Ribeiro 2018: 42).

Houve um grande erro na escolha do local da fábrica, pois ela ficava dentro do perímetro urbano e não tinha matéria-prima próxima, que deveria ser coletada nas extremidades do Parque Nacional Serra Capivara. Esse era um dos motivos que impossibilitava a extração da matéria-prima, pois o parque era um local de preservação e conservação ambiental. Apesar de a extração ser feita em locais que não estavam dentro do perímetro do parque, conforme aumentava a demanda a matéria-prima foi ficando escassa, e com isso foram gerados mais gastos em sua extração. Segundo o sr. Péricles, em dado momento não havia mais local para extrair matéria-prima, o que ocasionou o fechamento da fábrica. Logo após a fábrica foi fechada e todo o maquinário foi vendido para as fábricas de Coronel Jose Dias, Anísio de Abreu e Campo Maior.

O fechamento da fábrica acarretou imenso impacto no bairro Santa Luzia, causando o desemprego de várias pessoas que ali residiam. Foi um momento difícil para os moradores do bairro. Várias pessoas ficaram desempregadas e tiveram que buscar outras oportunidades de trabalho.

Após a desapropriação da fábrica, o local foi totalmente abandonado. O sr. Péricles Macário aproveitou os materiais construtivos do contexto fabril (especialmente a madeira dos telhados e as telhas) em outras construções. Uma parte do terreno foi vendida para terceiros e isso acarretou a desconfiguração do conjunto arquitetônico da fábrica. Atualmente o local está totalmente abandonado e tem fácil acesso para quaisquer pessoas. Mesmo assim, ainda existem estruturas que revelam os espaços do antigo contexto fabril.

\section{Contexto arqueológico da Fábrica de Cerâmica Castanheiro}

A partir de prospecções não interventivas identificamos alguns elementos arquitetônicos e objetos que faziam parte do contexto fabril que nos auxiliam a compreender a lógica interna de distribuição do espaço, bem como as diferentes etapas de produção.

Optamos por apresentar inicialmente os espaços e estruturas relacionados ao processo de queima, devido a seu grande impacto visual na paisagem do sítio, e, posteriormente, os espaços e estruturas associados ao processo de fabricação e armazenamento (produção dos objetos, secagem, armazenamento de matéria prima etc.) realizados na fábrica.

Sem dúvidas a chaminé é o elemento arquitetônico mais imponente do sítio (Fig. 2). Trata-se de um verdadeiro marco paisagístico do bairro, chamando a atenção de quem passa pela antiga fábrica, sendo visível também a partir de vários pontos da cidade. A chaminé é construída em tijolo maciço e argamassa de cal. Sua estrutura é composta por três partes distintas: a base, o fuste e a coroa. Sua base tem em torno de quatro metros de largura por quatro metros de comprimento; o fuste tem aproximadamente trinta metros; e, no seu topo, fica a coroa, com cerca de um metro e formato circular.

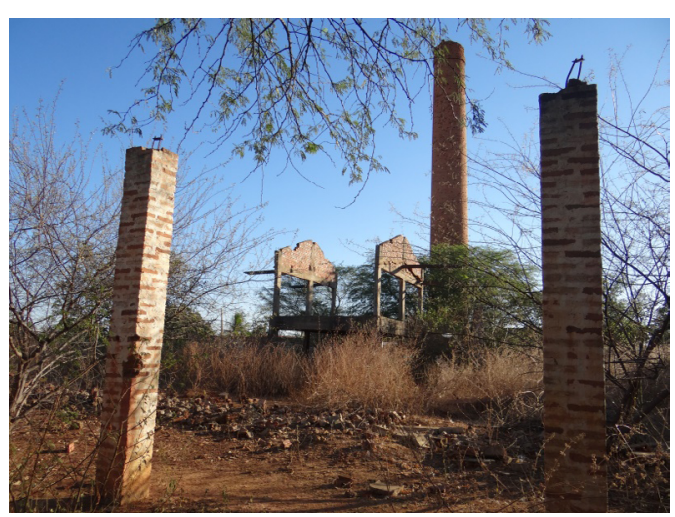

Fig. 2. Chaminé e estruturas do telhado da Fábrica de Cerâmica Castanheiro.

Fonte: Ribeiro (2018: 46).

A chaminé tinha um papel fundamental no processo produtivo da fábrica, exalando os gases provenientes do processo de queima das telhas e tijolos. Assim, todos os fornos da fábrica eram interligados por um sistema subterrâneo, que, 
além de promover a circulação de ar necessária ao processo de queima, levava a fumaça até a chaminé. Durante as prospecções pudemos identificar as estruturas (Fig. 3) que integravam esse sistema subterrâneo de exaustão dos fornos e que levava a fumaça até a chaminé.

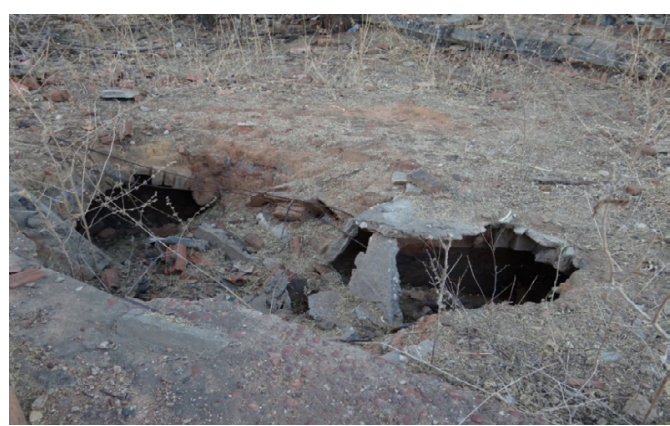

Fig. 3. Sistema subterrâneo de exaustão dos fornos. Fonte: Ribeiro (2018: 47).

Como mencionado anteriormente, com o aumento da produtividade na fábrica após a aquisição do sr. Péricles, foi necessário construir exaustores auxiliares para dispersar o calor que os fornos geravam devido à alta produtividade. Assim, foram construídos quatro exaustores interligados por um sistema subterrâneo igual ao dos fornos. Em campo conseguimos identificar a estrutura de apenas um desses exaustores (Fig. 4), que tem aproximadamente sete metros de altura e formato quadrangular, tendo sido construído com lajotas do tipo que era produzido na fábrica. Também conseguimos localizar o sistema subterrâneo ao qual os exaustores estavam interligados. Era constituído por uma plataforma de concreto armado (laje) que cobria as canaletas que levavam o calor até os exaustores. Parte da estrutura desse sistema subterrâneo encontra-se danificada, sendo possivel perceber que houve um processo intencional de demolição dessa estrutura (Fig. 5).

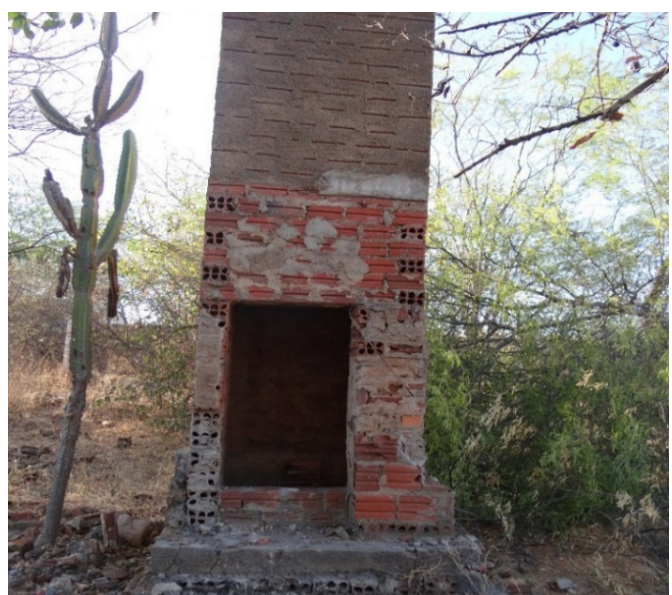

Fig. 4. Exaustor usado na dispersão de calor na Fábrica Castanheiro.

Fonte: Ribeiro (2018: 48).

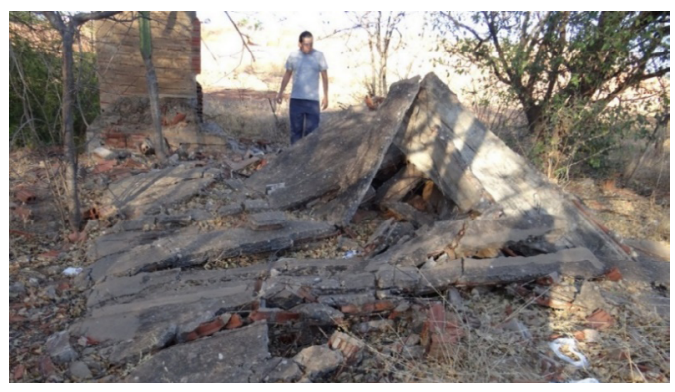

Fig. 5. Estrutura de laje que cobria a canaleta que se ligava ao exaustor.

Fonte: Ribeiro (2018: 49).

Apesar de não ter sido possível identificar a estrutura dos fornos durante os trabalhos de prospecção, por meio do levantamento iconográfico conseguimos imagens (Fig. 6) que revelam a dimensão e o formato dos fornos. Como podemos observar, os fornos eram construídos em tijolo maciço, tinham forma circular, com teto abobadado e uma abertura em arco, por onde as telhas e tijolos eram colocados no interior do forno e que era vedada durante o processo de queima. 


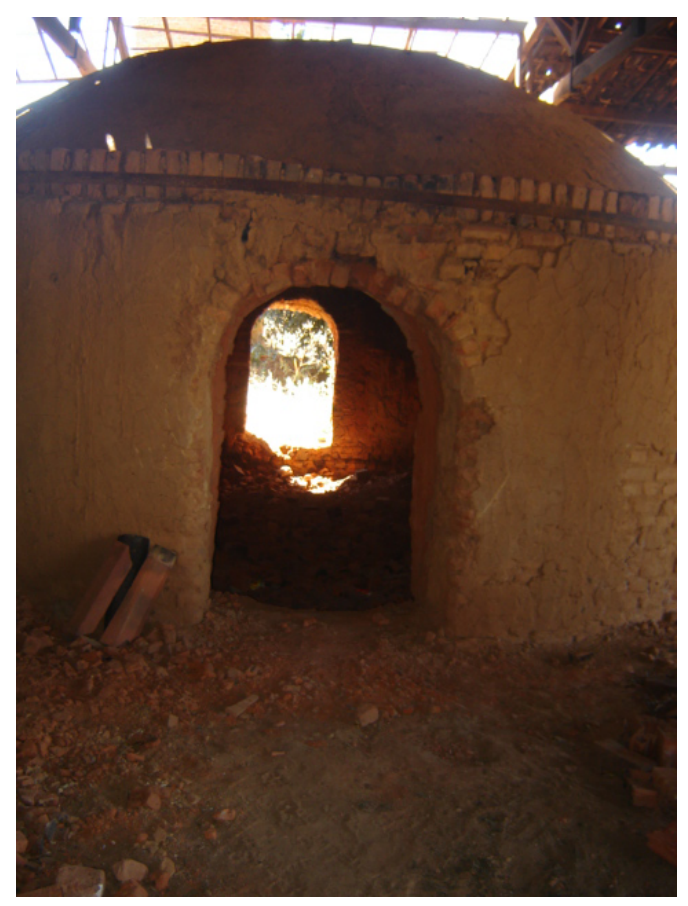

Fig. 6. Antigo forno, imagem registrada em 2006. Fonte: Foto de Darlan Ribeiro, 2006.

Ao lado da chaminé há uma estrutura de aproximadamente doze metros que fazia parte do telhado. Segundo o sr. Péricles Macário, essa estrutura era mais alta e aberta nas laterais para promover a ventilação no local onde os blocos e as telhas secavam até estarem prontos para queima (Fig. 1).

De modo geral, a estrutura de concreto armado garantia que, na extremidade do pátio de estocagem, o pé-direito do telhado fosse mais alto, promovendo uma abertura lateral em ambos os lados, o que otimizava a ventilação do interior do pátio de estocagem. A estrutura de ventilação da área de secagem do sítio ainda se encontra bem conservada, talvez por ter sido construída em concreto armado. Essa estrutura não foi demolida após o fechamento da fábrica, mas as telhas e o madeirame que compunham a cobertura foram retirados, o que explica a baixa incidência desse tipo de objeto no contexto do sítio.

Além dessa estrutura de ventilação, identificamos durante a prospecção outras estruturas arquitetônicas que integravam e delimitavam os espaços das áreas de produção/ armazenamento da fábrica. Assim, no sítio foram registrados dois corredores com colunas que ajudavam na sustentação do telhado.

No corredor principal, onde eram produzidos os tijolos e as telhas e onde estava instalado todo o maquinário da fábrica, as colunas tinham uma distância de quatro metros entre si no sentido norte-sul (Fig. 7), e no sentido leste-oeste elas tinham a distância de dez metros entre uma e outra. As colunas maiores têm cerca de 3,20 metros de altura e as colunas menores possuem 2,20 metros. Essa diferença de tamanho das colunas revela o ângulo de caimento do telhado da fábrica, que era de aproximadamente dez graus.

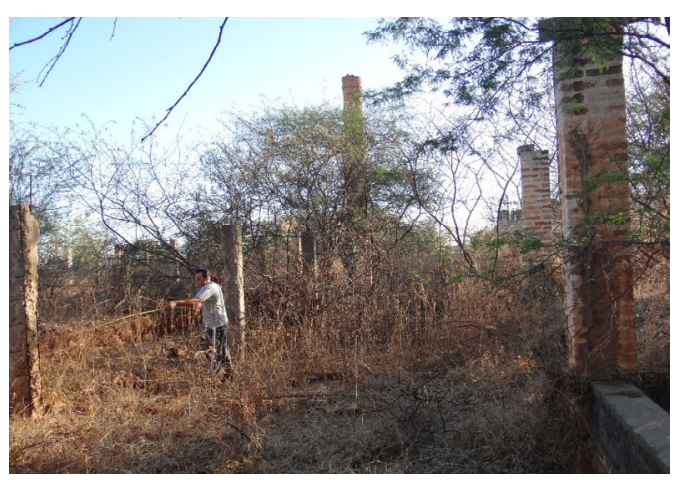

Fig. 7. Corredor norte e sul; área de produção. Fonte: Ribeiro (2018: 52).

Ainda no sentido norte-sul, há um outro conjunto de colunas formado tanto por estruturas de concreto armado quanto por lajotas de alvenaria. Essas colunas mantinham um distanciamento regular e integravam o sistema de sustentação do telhado da fábrica. Pode-se perceber que as colunas de lajota foram feitas posteriormente, provavelmente devido à ampliação da área de produção da fábrica.

Além disso, associado aos espaços de produção, podemos observar que a antiga fachada da entrada que dava acesso ao interior da fábrica ainda se encontra preservada (Fig. 8). A fachada foi construída com tijolos maciços e sua abertura principal possui 7,60 metros de comprimento, e altura máxima de cerca de 9,10 metros. 


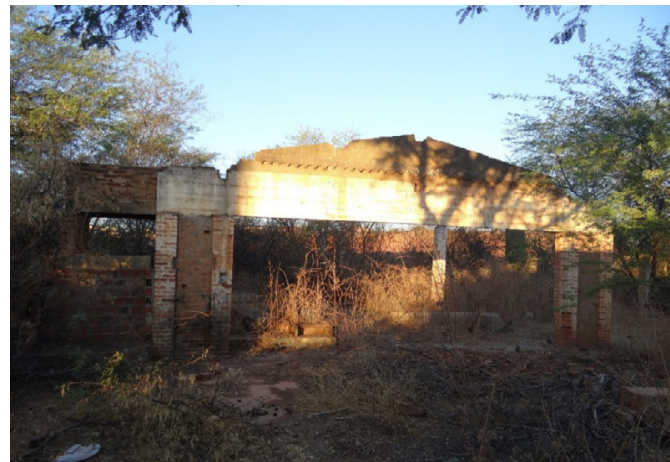

Fig. 8. Fachada da antiga Fábrica Castanheiro. Fonte: Ribeiro (2018: 54).

Logo ao lado dessa fachada há dois reservatórios de água (Fig. 9) que eram usados para molhar a argila e realizar sua decantação para a preparação dos materiais que eram confeccionados na fábrica. Essas estruturas apresentam um bom estado de conservação.

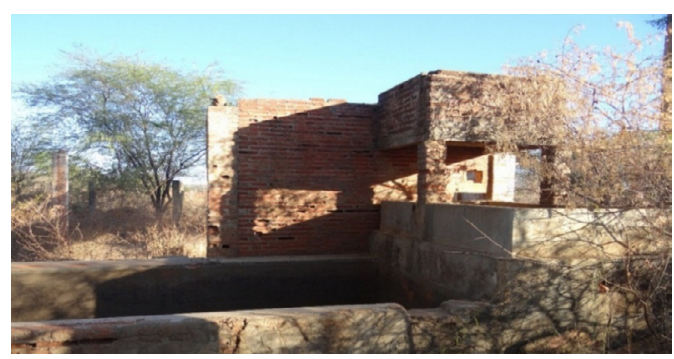

Fig. 9: Reservatórios de água e decantação.

Fonte: Ribeiro (2018: 56).

Ao lado dos reservatórios de água encontrase uma estrutura, localizada no principal galpão da fábrica, na qual ficava fixada a máquina conhecida como maromba (Fig. 10). Essa máquina era responsável por dar forma aos materiais produzidos na fábrica. Depois de todo o processo de preparação a argila era colocada na maromba, e os materiais iam ganhando forma de blocos ou telhas. Logo depois de ganharem forma os materiais eram levados para o galpão de secagem até estarem no ponto de queima.

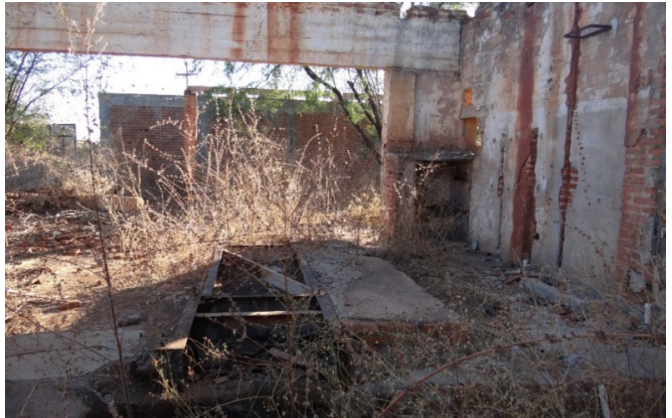

Fig. 10: Local onde estava fixada a maromba. Fonte: Ribeiro (2018: 58).

Esse galpão abrigava o local onde a argila era preparada para a produção de blocos e telhas. Esse local se chamava caixa de argila e ali a matéria-prima era armazenada depois de passar por um processo de limpeza, havendo uma pessoa responsável por retirar todos os materiais orgânicos e impurezas que se encontravam na argila. Em seguida a argila era colocada no caixão alimentador e passava por um processo de decantação até ficar pronta para ganhar a forma dos materiais que eram produzidos na fábrica.

Durante as prospecções conseguimos identificar a estrutura do Caixão Alimentador (Fig. 11), que possui 5,50 metros de comprimento por 3,50 metros de largura e mais de dois metros de profundidade, aproximadamente.

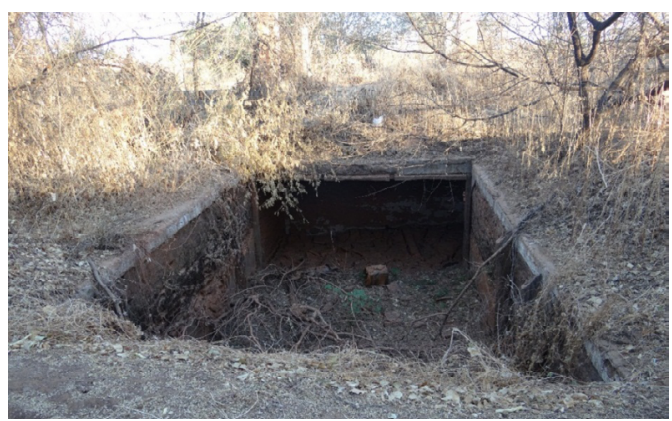

Fig. 11. Caixão alimentador da Fábrica Castanheiro. Fonte: Ribeiro (2018: 59). 
O caixão alimentador contém um corredor, que era utilizado para transportar a argila até a maromba, com cerca de 1,60 metro de largura e doze metros de comprimento, e uma rampa com inclinação de $45^{\circ}$ que facilitava a extração da argila (Fig. 12).

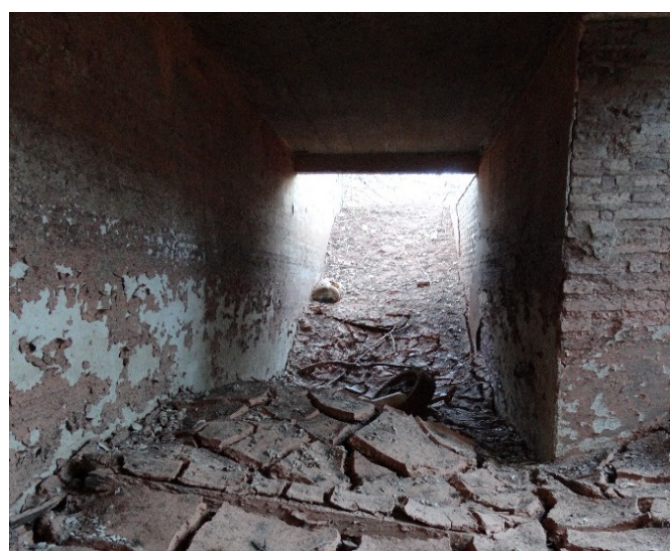

Fig. 12. Corredor que caixão alimentador a área de produção; maromba.

Fonte: Ribeiro (2018: 60).

Durante a prospecção localizamos, dentro desse corredor, um artefato que aparentemente fazia parte das engrenagens de algum maquinário (Fig. 13). O objeto tem formato circular, com alguns dentes, e aparentemente é uma peça de tração que poderia auxiliar na extração da argila de dentro do caixão alimentador.

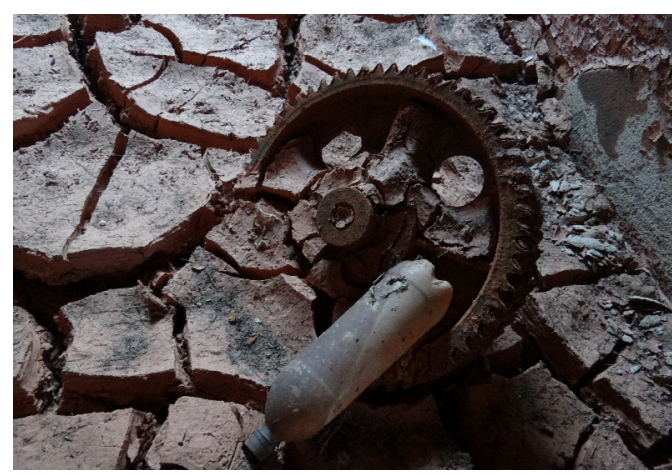

Fig. 13. Engrenagem localizada dentro do corredor do caixão alimentador.

Fonte: Ribeiro (2018: 61).
Além disso, dentro do caixão alimentador também foi encontrada uma lata com uma corda (Fig. 14). Acredita-se que essa lata era utilizada para extrair a argila do interior do local de armazenamento.

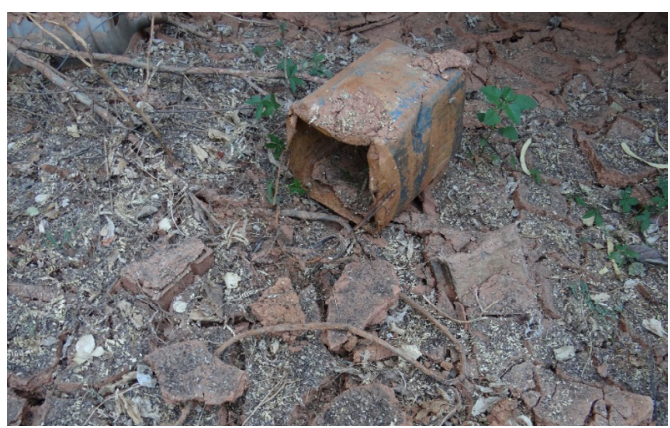

Fig. 14. Lata encontrada dentro do caixão alimentador. Fonte: Ribeiro (2018: 62).

De modo geral, o conjunto arquitetônico da Fábrica de Cerâmica Castanheiro encontrase bastante degradado devido ao abandono e a ações intencionais de demolição das estruturas.

\section{Reconstituição em 3D da Fábrica de Cerâmica Castanheiro}

Como mencionado anteriormente, após o encerramento das atividades produtivas o conjunto arquitetônico da Fábrica de Cerâmica Castanheiro passou por uma série de intervenções que promoveram a destruição e desconfiguração das estruturas e espaços fabris. Desse modo, buscamos reunir dados e informações que nos permitissem identificar e compreender os espaços, bem como elaborar uma reconstituição gráfica da fábrica.

Cabe destacar que a modelagem gráfica já vem sendo empregada há alguns anos por arqueólogos brasileiros como recurso para a representação e interpretação dos contextos arqueológicos, como exemplificado pelo trabalho de Bornal (2008) no Sítio São Francisco. Além disso, como discutido por Cavalcanti (2019), a confecção das maquetes 3D pode ser uma importante ferramenta para 
a divulgação e preservação do patrimônio histórico e arqueológico.

Assim, para tentarmos entender como era a ocupação dos espaços dentro da Fábrica de Cerâmica Castanheiro, cruzamos as informações obtidas por meio das fotografias, entrevistas e prospecções. Todas essas informações foram essenciais para o desenvolvimento de uma maquete 3D por meio dos softwares Sketchup e Lumion8.

Visto que durante o levantamento documental não tivemos êxito em localizar a planta original da fábrica, o antigo proprietário da fábrica, sr. Péricles Macário, fez um desenho da planta baixa, referência que foi empregada para a elaboração de um croqui que utilizamos para construir a maquete 3D da fábrica. Nosso interesse em desenvolver um modelo digital surgiu em decorrência da ausência da documentação imagética da fábrica e dos seus respectivos espaços durante seu período de funcionamento.
A modelagem do edifício foi realizada por meio do recurso de materiais e componentes do Sketch Up e a renderização por meio do plugin V-Ray; empregou-se também a ferramenta Shapes e Pull para a modelagem de elementos estruturais e não estruturais. Além disso, para a aplicação de texturas e materiais referentes ao acabamento do edifício utilizamos as ferramentas Materials e Scale, novamente com renderização realizada no plugin V-Ray ${ }^{10}$.

Assim, por meio do cruzamento das informações orais com os dados da prospecção conseguimos desenvolver um desenho da fábrica, fazendo o reconhecimento de cada espaço mediante uma planta baixa em 3D. Conseguimos identificar os quatro pátios de estocagem, o local de produção fabril, as duas subestações (chaminés), a área de armazenamento da argila e a área dos exaustores (Fig. 15).

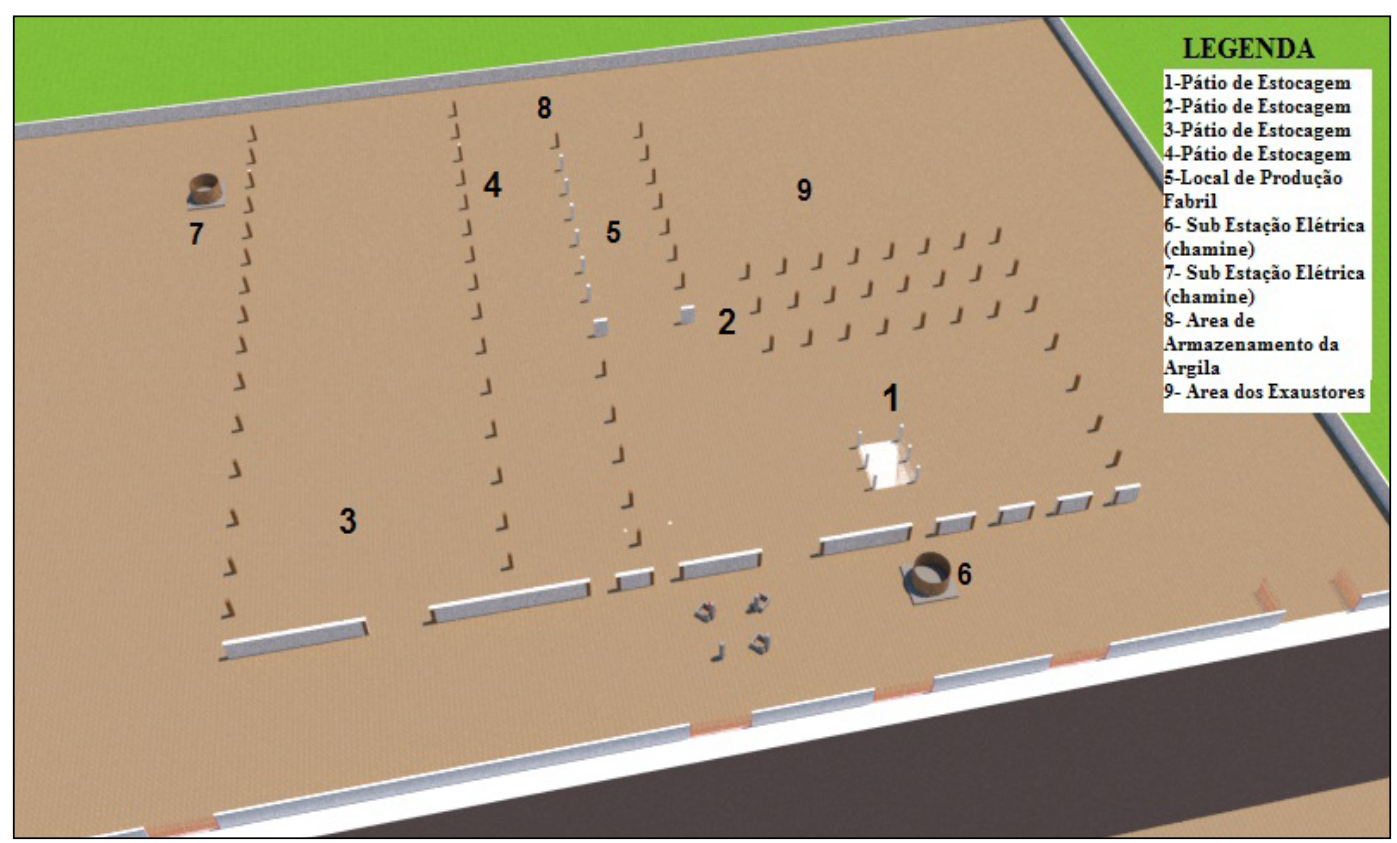

Fig. 15: Identificação dos espaços na fábrica.

Fonte: Ribeiro (2018: 70). 
A análise das fontes iconográficas e o relato do sr. Péricles Macário foram de suma importância para chegarmos a essa reconstituição em 3D da Fábrica de Cerâmica Castanheiro (Fig. 5), bem como na compreensão dos espaços que a constituíam.

Por meio do modelo elaborado (Fig. 16) podemos compreender como, possivelmente, ocorria o trânsito dos caminhões para a entrada de matéria-prima no local de armazenamento de argila, e a saída de produtos da fábrica.

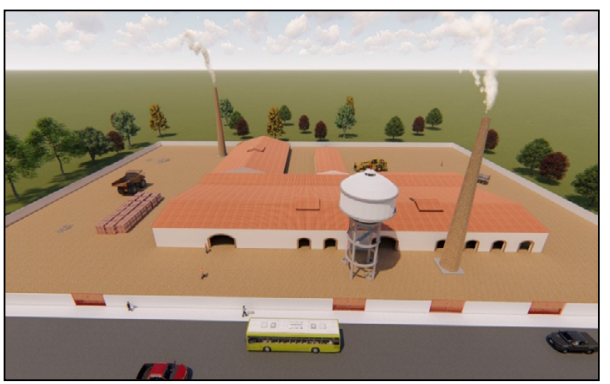

Fig. 16. Reconstituição em 3D da Fábrica de Cerâmica Castanheiro.

Fonte: Ribeiro (2018: 70).

Numa visão aérea (voo de pássaro) do modelo 3D (Fig. 17) conseguimos representar o local de estocagem dos materiais depois da queima, além do pátio de estocagem dos materiais antes da queima. Conseguimos também identificar a área de armazenamento da argila, o local de produção fabril e a área dos exautores. Por fim, podemos distinguir todos os espaços da fábrica e ter uma ideia de como se deu sua ocupação.

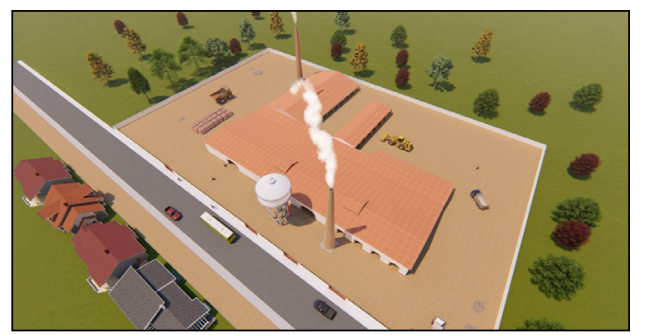

Fig. 17. Imagem da visão aérea da Fábrica de Cerâmica Castanheiro.

Fonte: Ribeiro (2018: 73).
Portanto, por meio da reconstituição da Fábrica de Cerâmica Castanheiro pelo modelo 3D conseguimos ter uma representação de cada espaço dentro da fábrica, identificar como eles eram designados e compreender como ocorreu a ocupação de cada espaço.

\section{Considerações finais}

A análise dos elementos presentes no contexto arqueológico da Fábrica de Cerâmica Castanheiro possibilitou inferir e analisar sua distribuição espacial e produtiva. Os vários elementos arquitetônicos e construtivos do sítio indicam as diversas intervenções que a fábrica sofreu desde sua inauguração até os dias atuais. Essas intervenções, ao mesmo tempo que formataram o registro arqueológico ora presente no sítio, também promoveram a "desconfiguração" do conjunto arquitetônico da fábrica, dificultando o reconhecimento de sua configuração espacial original.

Assim, por meio do contexto arqueológico, dos remanescentes arquitetônicos e das fontes orais e iconográficas buscamos identificar esses espaços e compreender sua funcionalidade no sistema de produção da fábrica. Nesse mister, pudemos determinar que a Fábrica de Cerâmica Castanheiro era composta por no mínimo cinco áreas ou espaços de produção, com funcionalidades distintas: o pátio de estocagem, o galpão de produção (que abrigava os maquinários), o local de armazenamento de matéria-prima (caixão alimentador), o galpão de secagem e os espaços e infraestrutura associados ao processo de queima (fornos/chaminé e sistema soterrâneo de exaustão).

Portanto, pudemos compreender que o processo de produção se iniciava com a extração da argila em jazidas um pouco distantes da fábrica (Novo Zabelê e Veredas). A argila era levada para a fábrica, onde ficava armazenada no caixão alimentador, onde passava por um processo de retirada de impurezas e decantação. Primeiramente a argila era inserida no destorroador, onde era feita uma limpeza e retirada dos materiais; em seguida ela passava pelo misturador, que homogeneizava a pasta 
a ser empregada na produção dos objetos cerâmicos. Posteriormente essa pasta alimentava os maquinários para a confecção das telhas e tijolos, inicialmente passando pelo laminador, que lhe conferia um formado de lâminas para, na maromba, adquirir o formato final desejado (telhas ou tijolos). O produto fabricado na maromba seguia para o pátio de secagem, onde permanecia até perder toda a umidade da pasta e atingir o ponto ideal para a queima, que acontecia nos grandes fornos existentes no interior da fábrica. Após o processo de queima, as telhas e tijolos eram encaminhados para o pátio de armazenamento e despachados para a comercialização.

Além de abordar os espaços e a lógica de produção na Fábrica de Cerâmica Castanheiro, esta pesquisa também buscou analisar a relação dessa fábrica com o desenvolvimento do bairro de Santa Luzia. Essa fábrica contribuiu tanto para o crescimento urbano do bairro, fornecendo o material construtivo para instalação do conjunto habitacional responsável por implantar em torno de duzentas casas na área, quanto para seu desenvolvimento socioeconômico, visto que gerou muitos empregos e atraiu pessoas de "fora" para residirem no local. A Fábrica de Cerâmica Castanheiro chegou a empregar, direta e indiretamente, cerca de cem funcionários, demonstrando que a economia do município de São Raimundo Nonato não se limitava apenas aos setores de serviço e agropastoril, mas também contava com uma produção industrial relevante.

Desse modo, a implantação da Fábrica de Cerâmica Castanheiro contribuiu gradativamente para o crescimento urbano do bairro Santa Luzia e para a cidade de
São Raimundo Nonato, visto que a fábrica precisava de muitos funcionários, que foram se instalando próximos ao local de trabalho, ocasionando a expansão geográfica do bairro e fomentando o comércio local.

Portanto, o estudo do contexto fabril abordado nesta pesquisa contribui para a compreensão do processo de industrialização local, e apresenta informações sobre um passado industrial recente, mas pouco conhecido do município de São Raimundo Nonato. O estudo da Fábrica de Cerâmica Castanheiro, por meio do ponto de vista da arqueologia industrial, possibilita compreender parte da industrialização do estado do Piauí e seu impacto no município de São Raimundo Nonato. Além disso, chama a atenção para a importância de uma história que se apaga à medida que uma fábrica ou os elementos associados ao contexto fabril se perdem, a partir de sua destruição, sem que haja um estudo que registre a materialidade e a espacialidade constituídas nesses locais.

No município de São Raimundo Nonato há alguns casarões, monumentos e a Fábrica de Cerâmica Castanheiro, que não são tombados ou protegidos por leis e ações, seja em nível municipal, estadual ou federal. Para que ocorra o tombamento desses bens culturais, sabemos que são necessários estudos que demonstrem sua relevância histórica e social. É em vista disso que este trabalho buscou discutir e demonstrar como a Fábrica de Cerâmica Castanheira fez e faz parte da história da cidade, pois, de certo modo, sua história se interliga às transformações sociais, econômicas e urbanísticas que ocorreram no município.

RIBEIRO, A.A.; AMARAL, A.M.; CARDOSO, R.A. Between structures and memories: analysis of Castanheiro Ceramics Factory from industrial archeology (São Raimundo Nonato/PI). R. Museu Arq. Etn. 36: 212-231, 2021.

Abstract: This article has as object of study the Castanheiro Ceramics Factory, which was active between 1980 and 2003 in the Santa Luzia neighborhood of the municipality of São Raimundo Nonato, state of Piauí, Brazil. By combining the theoretical methodological precepts of Industrial and Urban Archeology with the narratives of local residents, we seek to identify the productive spaces of the factory and problematize its importance for the spatial organization of the 
neighborhood, evaluating how the factory influenced urbanization, the process of industrialization and economic development of the municipality. Thus, by archaeological prospecting, semi-structured interviews and documentary surveys, it was identified that the factory was composed of five structures, with different functionalities: storage yard; production shed (housed the machinery); location of raw material storage (feed box); drying shed; and space associated with the burning process (ovens, chimney, underground exhaust system), this result allowed the elaboration of a 3D model of the factory. It was noticed that the factory contributed to the urban growth of the neighborhood, providing material for the construction of houses and for their socioeconomic development, generating jobs that attract people to live in the neighborhood and work in the factory, causing a geographical and demographic expansion. The factory employed 100 employees, demonstrating that the municipal economy was not limited to the service and agricultural sectors, having a relevant industrial production.

Keywords: Industrial Archeology; Fábrica de Cerâmica Castanheiro; 3D Model.

\section{Referências bibliográficas}

Agência Brasil. 2013. Iphan homologa tombamento da Estação Ferroviária de Teresina. Disponível em: $<$ https://bit.ly/2Od3DpC >. Acesso em: 19/03/2021.

Alarcão, J. 1994. Arqueologia das cidades. In: Anais do Encontro de Arqueologia Urbana, 1994, Braga.

Boni, V.; Quaresma, S. 2005. Aprendendo a entrevistar: como fazer entrevistas em ciências sociais. Em Tese 2: 68-80.

Bornal, W.G. 2008. Sítio histórico São Francisco: um estudo sob a ótica da arqueologia da paisagem. Tese de doutorado. Universidade de São Paulo, São Paulo.

Brasil. 1964. Lei no 4.380, de 21 de agosto de 1964. Disponível em: $<$ https://bit.ly/2PjK3sc $>$. Acesso em: 22/03/2021.

Cardoso, R.A. 2013. Arqueologia musealizada e educação patrimonial: caminhos e desafios da transmissão do conhecimento nos museus recifenses. Dissertação de Mestrado. Universidade Federal de Pernambuco, Recife.
Cavalcanti, M.R.B. 2019. Patrimônio virtual: a reconstrução em $3 D$ e a preservação do patrimônio cultural. Dissertação de mestrado. Instituto do Patrimônio Histórico e Artístico Nacional, Rio de Janeiro.

Cerdà, M. 2008. Arqueología industrial. PUV, València.

Clarke, K.; Palmer, M.; Neaverson, P. 1999. Industrial archaeology: principles and practice. Routledge, London.

Foley, V.P. 1968. On the meaning of industrial archaeology. Historical archaeology 2: 66-68.

Hodder, I. 1999. The archeological process: an introduction. Blackwell, Oxford.

Lucchese, M.C; Rossetto, R. 2018. A política urbana no governo militar (1964-1985). In: Bonduki, N. (Org). A luta pela reforma urbana no Brasil: Do Seminário de Habitação e Reforma Urbana ao Plano Diretor de São Paulo. Instituto Casa da Cidade, São Paulo, 35-80. 
Luna, S.V. 1999. Planejamento de pesquisa: uma introdução. Educ, São Paulo.

Moraes, I.A. 2005. Memória social: solidariedade orgânica e disputa de sentidos. In: Gondar, J.; Dodebei, V. (Orgs.). O que é memória social. Contra Capa, Rio de Janeiro, 89-104.

Noivo, M.I.B.C. 2010. Percurso pela Alfama arqueológica. Dissertação de mestrado. Universidade Nova de Lisboa, Lisboa.

Oliveira, M.B. 2015. SketchUp aplicado ao projeto arquitetônico: da concepção à apresentação de projetos. Novatec, São Paulo.

Ribeiro, A.A. 2018. Contribuições para a arqueologia industrial de São Raimundo Nonato-PI: a Fábrica de Cerâmica Castanheiro e o desenvolvimento do bairro Santa Luzia. Trabalho de Conclusão de Curso. Universidade Federal do Vale do São Francisco, São Raimundo Nonato.

Ribeiro, A.A; Alves, S.P.R. 2017. Memórias e histórias do Bairro Santa Luzia em São Raimundo Nonato-
PI. In: Anais do Pet-Arqueologia, 2017, São Raimundo Nonato.

Santos, A.F. 2014. Potencialidade da arqueologia industrial em Sergipe: estudo de caso da Fábrica de Tecido Sergipe Industrial. Trabalho de Conclusão de Curso. Universidade Federal de Sergipe, Laranjeiras.

Secult. 2018. Bens tombados e registrados do Piauí. Disponível em: <https://bit.ly/3czcUBG >. Acesso: 19/03/2021.

Silva, R.B. 1999. Concepções de arqueologia urbana em Lisboa. In: Anais do $2^{\circ}$ Colóquio Temático Lisboa Ribeirinha, 1999, Lisboa.

Souza, R.A. 2013. Arqueologia em fábricas paulistas, entre chaminés e estacionamentos: ou dos métodos para escavar uma fábrica. Revista $C P C$ 16: 136-173.

Vichnewski, H.T. 2004. As indústrias Matarazzo no interior paulista: arquitetura fabril e Patrimônio Industrial (1920-1960). Dissertação de Mestrado. Universidade Estadual de Campinas, Campinas. 